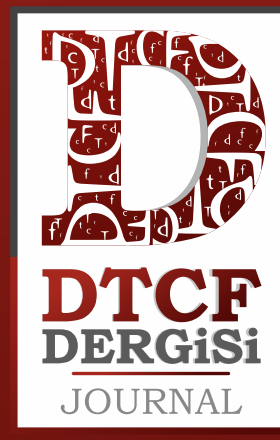

Makale Bilgisi

Gönderildiği tarih: 2 Mart 2021

Kabul edildiği tarih: 31 Mart 2021

Yayınlanma tarihi: 24 Haziran 2021

Article Info

Date submitted: 2 March 2021

Date accepted: 31 March 2021

Date published: 24 June 2021

Anahtar sözcükler

Sözcük Yapımi; Bileşik Sözcük; Ara

Ek; Neolojizm; Rol Dökümü

Keywords

Word-formation; Compound; Interfix; Neologism; Thematic Relation

\section{LEHÇE BİLEŞİK SÖZCÜKLERİN YAPISAL, İŞLEVSEL VE ANLAMSAL INCELEMESI}

\author{
STRUCTURAL, FUNCTIONAL AND SEMANTIC STUDY OF POLISH \\ COMPOUND WORDS
}

\section{Emrah GAZNEVI}

Dr. Öğr. Üyesi, İstanbul Üniversitesi, Edebiyat Fakültesi,

Slav Dilleri ve Edebiyatları Bölümü, Leh Dili ve Edebiyatı Anabilim Dalı, e.gaznevi@gmail.com

\begin{abstract}
$\ddot{O z}$
İki ya da daha fazla sözcüğün dil bilgisi kurallarına uyarak belirli şekiller içinde bir araya gelmesiyle yeni bir kavrama karşılık gelecek biçimde kullanılması anlamina gelen bileştirme, Lehçede sözcük türetme yollar içerisinde en çok başvurulan yöntemlerden biridir. Çalışmada Lehçe bileşik sözcüklerin yapısal çeşitliliği ve bazı özellikleri ele alınacaktır. Bu özelliklerin arasında en karakteristik olanı birleşiği oluşturan sözcükler arasında ara ekin görülmesidir. Bunun yanında birleşik sözcükler tümleyen, niteleyici, stralı birleşik olarak ele alınacaktır. Ayrıca iç merkezli ya da dış merkezli olmaları bakımından da değerlendirilecektir. Son olarak anlamsal açıdan incelenecek olan birleşik sözcüklerioluşturan bileşenlerin nasıl değişimlere uğradıkları tespit edilecektir.
\end{abstract}

\begin{abstract}
Compounding, which means that two or more words are used in a way that creates a new concept in accordance with the rules of grammar grammatical in certain forms, is one of the most used methods of word derivation in Polish language. In this paper, structural diversity and some features of Polish compound words will be discussed. The most characteristic of these features is that the interfix appears between the words in the compound. In addition, compound words will be examined in the form of subordinative, attributive, coordinative. It will also be discussed in terms of whether they are endocentric or exocentric. Finally, it will be determined how the components that form the compound words, which will be examined semantically, undergo changes.
\end{abstract}

\title{
Giriş
}

Değişen dünyada sosyokültürel ve teknoloji alanında yaşanan gelissmeler beraberinde yeni sözcüklere olan ihtiyacı da getirmiştir. Yaşayan her dilde geçmişten bugüne kadar sayısız sözcük türetilmiştir ve dilin doğası gereği türetilmeye devam edecektir. Dilin tipolojisine bağlı olarak sözcük türetme yöntemlerinde farkl1lıklar görülebilir. Birtakım ön ve son ekler yardımıyla sözcük türetmenin yanı sıra iki ya da daha fazla sözcüğün birleştirilerek yeni bir sözcük oluşturulması anlamına gelen birleştirme çok yaygın ve üretken yöntemler arasındadır. Bükünlü dil olan Lehçenin sözcük köklerindeki ünlülerde ses değişikliği meydana gelebilmektedir. Bu değişikliğin izlerine sözcük türetmede de rastlanır. Lecieć 'uçmak' fiilinin kökünde görülen ses değişikliği sonucu türemiş olan lot 'uçuş' adi bu tür sözcüklere verilebilecek örnekler arasındadır. 
Birleştirme de kendi içinde biçim bilimsel açıdan farklı türlere sahiptir. Sifat+sifat, zarf+sifat, say1+sifat, isim+sıfat, sifat+isim, say1+isim, isim+isim, isim+fiil, say1+fiil, zarf+fiil gibi farklı türde sözcüklerin birleşimi sonucu yine farklı sözcük türleri ortaya çıkar. Bu birleşim formülleri de yöneten baş ögesi olan yapılar, eşitsel/sıralı yapılar şeklinde yine kendi içinde bazı sınıflara ayrılır.

Türkçede dilbilim terimi olarak "birleşik/bileşik sözcüğe" dair yapılan tanımlar, açıklamalar ve verilen örnekler şöyledir: "Birleşik (compound): iki ya da daha çok bağımsız birimden oluşan, anlam bakımından baş işlevini gören sözcügün alt sınıfını belirten yapı. Türkçe'de tamlamalar birleşik yapı örnekleridir; örn. çamaşır makinası, çocuk arabası, okul çantası, dilbilim, vb." (İmer, Kocaman ve Özsoy 59). Bileşik sözcüğe ilişkin olarak da şu tanım sunulur:

İki ya da daha çok sözcüğün dilin kuralları doğrultusunda bir araya gelmesi ve kalıplaşmasıyla oluşup anlamlı tek bir birim işlevi gören, anlamı kendini oluşturan sözcüklerin anlamından bağımsız bir sözlüksel birim niteliği taşıyan dizim; örn. bilgisayar, arapsaçı, hanımeli, bilirkişi, gelgit, büyükelçi, denizaltı, ağaçkakan, biçerdöver, dişbükey, vb. (İmer, Kocaman ve Özsoy 56).

Berke Vardar ise bileşik sözcük başlığı altında konuya "İki ya da daha çok sözlük birimin kaynaşıp kalıplaşmasıyla oluşan ve anlamlı bir tek birim işlevi gören öge (örn. hanımeli, binbaşı, dilbilim vb. sözcükler)” (Vardar 44) şeklinde açıklık getirmiştir. Paylaşılan bu bilgiler doğrultusunda dilimizde bileşik sözcüklerin bitişik yazılan sözcüksel biçimbirimlerin yanı sıra tür belirtmesine bağlı olarak birbirinden ayrı yazılan bağımsız birimlerden de oluştuğu söylenebilir.

İki ya da daha fazla birimin bir araya gelmesiyle bileşik sözcük oluşturma Lehçede de çok sık başvurulan yöntemlerden bir tanesidir. Fakat bu çalışmada ele alınacak Lehçedeki bileşik sözcükler yapı bakımından Türkçe bileşik sözcüklerden ayrılır. Bunun nedeni Slav dili ailesine ait diğer pek çok dil gibi Lehçenin de farklı bir eke sahip olmasıdır. Bu ek birbirine bitişik yazılan iki bileşenin arasında görülür. Oluşum biçimlerine göre kendi başına bir sözcük türü olan bileşik sözcüklerin bu dildeki farklı yapıya sahip olmasının bir nedeni de sözcük gruplarından sayılan belirtisiz ad tamlamasının olmayıșına dayanır. Türkçede belirtisiz ad tamlaması kullanıldığı durumlarda Lehçede bileşik sözcüğün oluşturulduğu kesin bir dille ifade edilebilir. 
Lehçede bileşik sözcük yapımında karakteristik olarak farklı sözcük birimleri birbirine bağlamaya yarayan ara ekler ${ }^{1}$ kullanılır. Bu bileşik sözcükler życi-o-rys (hayat - bağlama ünlüsü - kısa betim/özellik) 'özgeçmiş' ve par-o-statek (buhar bağlama ünlüsü - gemi) 'buharlı gemi', mebl-o-ścianka (mobilya - bağlama ünlüsü duvar) 'duvar ünitesi' şeklinde bir ara ek ünlüsüyle bağlanmış iki kökten oluşabilir.

Bu tür oluşumlar iki anlamsal sözcügün kökü üzerinde şekillenir. Bileşik sözcüğün bileşenleri, bir ek olan -o- ara ekiyle bağlanır. İkinci bileşende son ek ya da sıfır morfem şeklinde adlandırılan ortak ek vardır. İkinci bileşen aynı zamanda bağımsız bir ifade olabilmektedir. Bileşiklerin köklerini kaynaştırmak için anılan yöntemlerin birkaç istisnas1 vardır. İkinci birimin kökü, bir fiil veya bir ismin köküdür, birinci birim sıfat, zarf ve rakam gibi dilin diğer ögelerinin köklerini de içerebilir. Yapısal anlamı, bileşiğin her iki üyesi arasındaki ilişkiden kaynaklanır. (Bartnicka ve Satkiewicz 242).

İstisnalardan biri ise słodko-gorzki 'ac1 tatlı' gibi kısa çizgiyle ayrılmış olmalarıdır, ancak yine de tek bir yazımsal sözcük olarak kabul edilir.

Yukarıda sözü edilen Lehçe bağlama ünlüsü Türkçede tamlanan eki ile kıyaslanabilir. Sağ tarafta -(s)I(n) son ekli Türkçe ad+ad birleşmeleri genellikle "iyelik öbeği" veya sadece "birleşik" olarak adlandırılır. -sI son ekine ya "durum belirleyici" ya da "bağlantı öğesi" adı verilir ve genellikle üçüncü tekil şahıs uyumlu iyelik son ekinden kaynaklandığı söylenir, ancak "çamaşır makinesi, kap1 kolu" gibi bu birleşimler sahiplik anlamı taşımaz. (Bağrıçıı ve Ralli 332-333).

Lehçe birleşiklerde bileşenler bir araya gelerek, baş ögesi ikinci kısımda olan tek bir biçim bilimsel sözcük oluşturur. Büküm eki mebl-o-ścian-k-a (mobilya + bağlayıcı ünlü + duvar + küçültme eki + nominatif-tekil) örneğindeki gibi sağ taraftaki gövdeye, a ünlüsüne eklenir. Stawonóg gibi diş merkezli birleşiğin tamlayan durum eki almış halinin staw-o-nog-a (eklem + bağlayıcı ünlü + ayak + genitif-tekil) çekimsel bitimi, kökte ses değişikliği yaratarak bir bütün olarak birleşiğin gövdesine eklenmiş gibi görünmektedir, çünkü bu tür birleşik isimlerin çekim biçimleri sağ bileşenin bağımsız haldeyken çekim özelliklerinden farklıdır. Hiçbir durum ekiyle çekimlenmemiş bileşik sözcük stawonóg 'eklem bacaklılar' erildir, fakat bileşiği oluşturan 'ayak' anlamına gelen sağ taraftaki sözlük birimin nominatif hali noga dişildir. Bu dişil adın tekil genitif hali nogi iken yukarıda anılan bileşiğin sağ kurucusu olduğunda tekil genitif durum ekiyle çekimlenmiş hali -noga'dır ve sanki

\footnotetext{
${ }^{1}$ Lehçe dilbilim terminolojisinde interfiks ya da międzyrostek olarak adlandırılmaktadır.
} 
yalın haldeymiş gibi görünür. Dahası bağımsız bir sözcük olarak söz konusu dişil ad çoğul genitif durumda nóg iken, bileşiğin sağ kurucusu konumundayken tekil nominatif durumda stawonóg biçimini alır. Bunun nedeni Lehçede birleşik sözcükleri oluşturan bir kısım bileşenlerin, birleşme esnasında bazı sesleri düşebilir. Basit sözcük hali ile bileşiğin ögesi konumundayken son derece ilginç ve de yanılgiya düşürebilecek bitimleri tek bakışta gösterebilmek adına şöyle küçük bir tablo verilebilir:

\begin{tabular}{|l|l|l|l|}
\hline & Nominatif (tekil) & Genitif (tekil) & Genitif (çoğul) \\
\hline Bacak & noga & Nogi & nóg \\
\hline Eklem bacaklilar & stawonóg & Stawonoga & stawonogów \\
\hline
\end{tabular}

Aynı şekilde 'halk müziği grubu' kapela sözlük birimiyle oluşturulan, 'orkestra şefi' kapelmistrz birleşiğine bakıldığında, kapela bileşeninde ses düşmesi görülür. Bu gibi daha pek çok örnek verilebilir.

Sözlük birimi olma özelliği taşıyan ve ortak bileşene sahip birtakım Lehçe bileşik sözcükler, her zaman aynı bileşenle benzer yap1 ve tipte bileşik oluşturma konusunda yanıltıcı olabilir. Çünkü 'ölçer, ölçüm cihaz1' -mierz birimi ile gazomierz 'gazölçer, gazometre' ciśnieniomierz 'basıölçer, barometre' głębokościomierz 'derinlikölçer' amperomierz 'akımölçer' gibi pek çok bileşik Lehçe sözlüklerde madde baş1 olarak yer alırken, 'isıölçer' *temperaturomierz, 'renkölçer' *koloromierz, 'sesölçer' *dźwiękomierz gibi yapılar söz konusu olamaz. Bu kavramlar ancak sırasıyla miernik temperatury, miernik koloru, miernik dźwieku/hałasu şeklinde tamlama yöntemiyle karş1lık bulur. Bazen de bileşik sözcüğün anlamı aynı zamanda tamlama yoluyla sunulur. 'Hızölçer' hem szybkościomierz şeklinde bileşik sözcük hem de miernik szybkości gibi tamlama biçiminde; 'nemölçer' wilgotnościomierz şeklinde bileşik sözcük yardımıyla veya miernik wilgotności gibi tamlama yoluyla ifade edilebilir. Kıyaslandıklarında her ne kadar yapısal farklılıklar gözetilse de semantik açıdan hiçbir fark yoktur. Yapısal zenginlik konusunun daha da ilginç yanı Lehçe tamlama içinde bileşik sözcüğün yer almasıdır: ‘hava nemi ölçer’ Lehçeye miernik wilgotności powietrza zincirleme ad tamlamas1 veya wilgotnościomierz powietrza ad tamlamas1 yöntemiyle aktarılır. Bu ad tamlamasında tamlanan görüldüğü üzere tür olarak bileşik sözcüktür. Fakat *powietrzowilgotnościomierz gibi bir yazım doğru kabul edilemez. Buna karşılık örneğin, 'aydınlık ölçer, lüksmetre'nin Lehçede miernik natężenia oświetlenia şeklinde tek bir biçimi vardır. 
Başka dillerden Türkçeye geçmiş bazı sözcükler Lehçe ve İngilizce birleşiklerle karşılaştırıldığında ilginç bir benzerlik göze çarpmaktadır. Birleşiğin iki birimi arasında -o- bağlayıcı ünlüsü yer aldığı görülür:

\begin{tabular}{|l|l|l|}
\hline Türkçe & Lehçe & Íngilizce \\
\hline gaz+o+metre (Fr.) & gaz+o+mierz & gas+o+meter \\
\hline bar+o+metre (Fr.) & bar+o+metr & bar+o+meter \\
\hline tak+o+metre (Alm.) & szybkości+o+mierz & speed+o+meter \\
\hline elektr+o+metre (Fr.) & elektr+o+metr & electr+o+meter \\
\hline akseler+o+metre (Fr.) & przyśpieszeni+o+mierz' & acceler+o+meter \\
\hline
\end{tabular}

Türkçe başlık altında toplanan böylesi sözcük oluşumlarının nedeni sözcüklerin her ne kadar diğer dillerden ödünçlenmiş olmasına bağlansa da yine yabanc1 kökenli sözcüklerden biri olan 'ampermetre' (Fr. ampèremètre) bağlayıcı ünlü barındırmamaktadır. Diğer yandan szybkość 'hız', przyspieszenie / przyśpieszenie 'ivme' ve mierz 'ölçer' hepsi her ne kadar Lehçe sözcük de olsalar birleşik oluştururken iki öge arasında bağlayıcı ünlü belirir.

Birleşik oluşturmanın farklı farklı yolları mevcuttur ve her dilde olduğu gibi Lehçede de sözcük türetmede başvurulan en yaygın yöntemlerden biridir. Bu yöntemin en önemli kuralı eklerin değil en az iki sözcüğün bir arada olması gerektiğidir. Çünkü ek olduğunda bileşik sözcük değil, halihazırda mevcut bir sözcükten türetme yapılmış olur. Birleşikler arasına ekin hiç gelmeyeceği yönünde bir ifadede bulunmak da doğru sayılmayacaktır. Ancak bu ekin sözcük türeten bir niteliğe sahip olmadığı unutulmamalıdır. Bu yönüyle söz konusu ekin türü iyi belirlenmelidir. Yapılarına göre sözcükleri Slav dil ailesine ait başka bir dil üzerinden ele alan bazı Türkçe kaynaklar incelendiğinde birleşiklerdeki bu ekin "iç ek" olarak adlandırıldığı gözlemlenmiştir. Ancak bu ek için "ara ek" teriminin kullanılması daha doğru olacaktır. Çekimli ya da içten kırılmalı olarak da adlandırılan bükümlü dillerden olan Lehçede sözcük köklerinin yapım ve çekim sırasında öne, içe, araya, sona ve aynı anda hem öne hem sona bazı ekler alarak farklı şekillere ve kırılmalara uğrar.

\footnotetext{
2 Przyspieszeniomierz şeklinde yazım şekliyle de karşılaşılır ve aynı anlama gelir.
} 
Birleşikler iki kök biçimbirimin ara ekler yardımıyla birleşerek oluşturduğu türemiş sözcüklerdir. Çoğunlukla -o-olmak üzere ilk konumda fiil kökü, rakam, sıfat ve ismin yer almasına bağlı olarak - $i-,-u$-ve $-y$ - sesleri Lehçedeki bir anlamda bağlama ögesi işlevi üstlenen ara eklerdendir. "Bir fiil gövdesinden ve onu takip eden ad gövdesinden oluşan birleşikler söz konusu olduğunda, gol-i-brod-a (tıraş et + birleştirme ünlüsü + sakal + nominatif.tekil) 'berber' ve mocz-y-mord-a (1slat + b. ünlüsü + ağız (argo) + nom.tekil) '(argo) sünger, ayyaş’ örneklerinde olduğu gibi ara ek -i-/-y- ünlüleridir. İlk bileşen $d w(u)$ - 'iki' rakamı olduğunda $d w$-u-znak (iki + b. ünlüsü + gösterge) 'tek sesi oluşturan iki harf' örneğindeki gibi ara ek, $-u$ - ünlüsü olarak kendini gösterir.” (Cetnarowska 283). Birleşiklerin çoğunlukla isim veya sifat olan iki bileşen gövdeyi birbirine bağlamaya yarayan birleştirme ünlüsü içerdiği görülür.

\begin{tabular}{|l|l|l|l|l|}
\hline \multicolumn{1}{|c|}{ Gövde 1 } & & \multicolumn{1}{|c|}{ Gövde 2 } & & \multicolumn{1}{c|}{ Bileşik Adlar } \\
\hline gwiazd·a 'yıldız' & + & $\begin{array}{l}\text { zbiór 'küme } \\
\text { takım' }\end{array}$ & $>$ & gwiazd-o-zbiór 'takımyıldız' \\
\hline siark·a 'sülfür' & + & wodór 'hidrojen' & $>$ & siark-o-wodór 'hidrojen sülfür' \\
\hline star·y 'eski' & & druk 'baskı' & & star-o-druk 'antika kitap' \\
\hline żyw·y 'canlı' & + & płot 'çit' & $>$ & żyw-o-płot 'çalı çit' \\
\hline łam-a·ć 'kırmak' & + & strajk 'grev' & $>$ & łam-i-strajk 'grev kırıc1' \\
\hline $\begin{array}{l}\text { mocz-y·ć } \\
\text { 'slatmak' }\end{array}$ & + & $\begin{array}{l}\text { mord·a 'ağ1z, } \\
\text { surat' }\end{array}$ & $>$ & mocz-y-mord·a 'ayyaş' \\
\hline dw·a 'iki' & + & głos 'ses' & $>$ & dw-u-głos 'dialog' \\
\hline dw·a 'iki' & + & $\begin{array}{l}\text { tygodnik 'haftalık } \\
\text { dergi' }\end{array}$ & $>$ & $\begin{array}{l}\text { dw-u-tygodnik 'iki haftada bir } \\
\text { yayımlanan dergi' (Cetnarowska 283). }\end{array}$ \\
\hline
\end{tabular}

\section{Lehçe Birleşiklerin Neolojizmle İlişkisi}

Dil, doğası gereği değişim içinde olan canlı bir varlıktır ve bu özelliği itibariyle söz varlığ sürekli gelişim halindedir. Evrensel bir olgu olan ve neolojizm olarak bilinen yeni üretilen bir kavrama yeni bir karşılığın verilmesi konusunda Lehçede -o- ara ekiyle oluşturulan bileşiklere zaman zaman başvurulduğu görülmektedir. Bu yeni ögelerin bazıları henüz sözlük birimi özelliği taşımaz. O yüzden bu kısımda paylaşılacak olan yeni sözcüklerin anlamları bileşenlerinden yola çıkarak saptanacaktır. 
Anlatımsal ve sözcüğün taşıdığı kavramı bildirir nitelikteki yeni öge (neolojizm) olan çok sayıda birleşikler, yalancı birleşikler ${ }^{3}$-o- ögesi içeren yapılara dahildir. Söz konusu isimlerin genellikle ilk kısmında auto- ('araba') ve sam- ögeleri vardır, ikinci kısminda ise: -biorca, dawca, -fobia, -logia, -mania, -terapia, -znawca; örneğin autobank 'otobanka'4, autosalon 'oto galeri', samoaborcja 'kendi kendine düşük yapma', samolustracja 'öz denetim', samoopodatkowanie 'kendi kendine vergilendirme', organobiorca 'organ bağışçısı', nasieniodawca sperm donörü, pedałofobia 'homofobi', podatkologia 'vergiloji', strajkologia 'grevoloji', Gołotmania 'Golota sevdalıları', konkursomania 'yarışma tutkunları' genoterapia 'gen terapisi', laseroterapia 'lazer terapisi', mitoznawca 'mitoloji uzmanı'. Barmanokelner 'barmengarson', barokawiarnia 'bar-kafe', młynkomikser 'öğütücü-mikser', nartorolka 'tekerlekli kayak, çim kayağı', pieluchomajtki 'alt bezi' gibi sıralı yapılar nispeten daha az düzenli yapıya sahip bileşiklere dahildir. (Jadacka 122-123).

Neolojizmlerin üretilmesinden önce bu anlamlara karşılık gelen sözcüklerin olup olmadığı sorusu akla gelebilir. Teknolojik, psikolojik, ekonomik, kültürel nedenlerden dolayı ortaya çıkan yeni nesne, kavram veya hareketleri adlandırma gereksinimi sonucu oluşturulmuş bileşikler dışında eski bir anlam için üretilen -oara ekli yeni ögelerden önce tamlama ( $\left.\operatorname{ad}+\operatorname{ad}_{\mathrm{GEN}}\right)$ kullanımı en sik başvurulan yöntemler arasındayd1. Kredytobiorca yeni üretilen eylemcil bileşiği ile biorca kredytu tamlaması 'borçlanan, kredi alan'; aynı şekilde yeni öge olan birleşik licencjodawca ile dawca licencji 'lisansör'; krwiodawca ile dawca krwi 'kan bağışçısı' şeklinde aralarında yapısal dişında anlamsal fark bulunmamaktadır.

Sözü edilen yeni türentilerin tartışmalara konu olmaya başlaması beraberinde farklı görüşlerin ortaya çıkmasına neden olmuştur. Örneğin -dawca 'veren, donör' bileşenli eylemcil birleşik modeli birçok rastlantısal boşluğa işaret eder. Bir başka deyişle dil bilgisi kuralları çerçevesinde oluşturulabilen ancak dilde bulunmayan olası bir sözcük veya bir forma işaret eder. İmkân dahilinde iyi biçimlendirilmiş organodawca 'organ donörü', szpikodawca '(kemik) iliği donörü' veya sercodawca

\footnotetext{
${ }^{3}$ Bazı birleşiklerin oluşumunda -mania, -bójca, -logia, auto-, geo-, -fon, -skopia gibi ön ekler/parçacıklar da aktif rol alabilmektedir. Ön ek ve parçacıklar tek başına kullanılamadığı, sözce oluşturamadığı, yani bağımsız biçimbirim kabul edilmediğinden bu yapılara yalanc1 birleşik adı verilmiştir. Yalancı birleşikleri oluşturan söz konusu parçacıkların pek çoğu Lehçeye yabancı dillerden (çoğunlukla Latince ve Yunancadan) geçtiği savunulmaktadır.

${ }^{4}$ Büyük otomotiv şirketleri tarafından oluşturulan ve kendi modellerinin satın alınması için otomobil kredileri veren bir banka türü.
} 
'kalp donörü' bileşiklerinin (Polonya Ulusal Korpusu'nda) hiçbir izi yoktur. (Cetnarowska 294).

\section{Birleşiklerdeki Vurgunun Özelliği}

En fazla üç seslemli birleşikler vurgu belirleme konusunda tek bir bürünsel birim oluşturur. Sözcükteki vurgu isimlerde veya sıfatlarda sondan bir önceki seslem üzerindedir. (örn. rękopis, stawonóg, włóczyki, listonosz samolot pięciokat). Fakat bileşik sözcük çok seslemli bir özelliğe sahipse sondan bir önceki seslemdeki ana vurgunun yanı sıra, ilk kurucuda ikincil vurgu görülebilir (językoznawstwo, ciemnobrązowy).

Bileşik sözcükler birbirinden ayrı yazılan sözcük gruplarıyla kıyaslandığında yalnızca yapısal bağlamda değil, ses bilgisel açıdan da farkl11ık gösterir. Üçten fazla sesleme sahip bileşik sözcüklerde birincil ve ikincil vurgu olmak üzere iki ayrı vurgu derecesi bulunur. Birincil vurgu ikinci bileşenin sondan bir önceki seslemi üzerinde, ikincil vurgu ise birinci bileşen üzerindedir. Brazowopłowy 'açık kahverengi' birleşiğinde daha kuvvetli, net ve yüksek tonda olan birincil vurgu płowy üzerinde görülürken, zayıf vurgu brazowo üzerindedir. Benzer biçimde zamanda noworoczny 'yeni yıla ilişkin' birleşiğinde birincil-ikincil vurgu olmak üzere iki ayrı vurgudan söz edilirken, nowy roczny gibi sözcük grubu oluşturulduğunda her iki sözcük de ana vurguya sahip olur.

Bazı birleşik türlerinde ara ekin kullanılmadığı bir diğer dikkatleri çeken unsurdur. Ara ekin düşmesi fonolojik özelliklerden kaynaklanabilmektedir. Birinci bileşenin son sesi ve/veya ikinci bileşenin ilk sesi titreşimliyse (półnuta 'ikilik', ćwierćlitrowy 'çeyrek litrelik', trójdźwięk 'üçgen' gibi) birleşim araya giren bir ek olmadan gerçekleşebilmektedir. Bu morfolojik durum birleşimlerin sayısal ifadeler barındırmasıyla da açıklanabilir. “Örneğin, trój- 'üç’ rakamı veya pót-'yarım’ ögesi içeren bazı birleşik türlerinde birleştirme ünlüsü bulunmaz: trójskok (üç + atlama) 'üç adım atlama', północ (yarim + gece) 'gece yarısı, kuzey'” (Cetnarowska 283).

Ara ekin eksikliği sözcüksel bağlamda belirlenebilir. Örnek olarak -mistrz 'şampiyon, usta' leksik birimi ele alındığında ve baş olduğu birleşiklerin bazılarına bakıldığında baletmistrz 'bale eğitmeni', kapelmistrz 'bando şefi', zegarmistrz 'saat ustası' gibi ara ekin bulunmadığı fark edilir. Fakat bu model biçimsel olarak tutarsızdır: baş ögesi -mistrz olan doğrulanmış bazı bileşikler ise her zamanki -o- ara ekine işaret eder. Örneğin, ogniomistrz 'topçu çavuşu' (ogień 'ateş'), organomistrz / organmistrz borulu org uzman1. (Kurzowa, $Z$ przeszłości i teraźniejszości języka 458). 
Toromistrz 'demir yolu uzmanı' gibi çeşitlendirilebilen daha pek çok birleşiklerde ara ekin varlığı tespit edilebilmektedir.

Diğer bileşenin sayı sıfatı olması şartıyla 'çok, fazla' anlamındaki wiele/wielu belgisiz niteleyici de ara ekin eksikliğinin sözcüksel bağlamda belirlenebilmesine ilişkin örnek teşkil eden bir diğer birimdir. Wielekroć 'çok kez', wieleset 'yüzlerce', wielesetkilometrowy 'yüzlerce kilometre(lik)' birleşiklerinde görüldüğü üzere herhangi bir ara ek yoktur. Öte yandan wielokierunkowy 'çok yönlü', wielokąt 'çokgen', wielokolorowy 'çok renkli', wielostopniowy 'çok aşamalı', wielofunkcyjność 'çok fonksiyonluluk' gibi bileşik sözcüklerde ise sayı sıfatı olmadığından iki birim arasında -o yardımcı sesi yer alır.

\section{Bileşik Sözcüğün Türüne Göre Kısa Çizgi Kullanımı}

Bileşik sözcükler kendi aralarında bileşik ad ve bileşik sıfat olmak üzere ikiye ayrılır. Eşdeğerli sıfat + sıfat birleşiminden oluşan bazı bileşik sıfatların iki ögesi arasında kısa çizginin olması bakımından bileşik isimlerden farklı bir oluşturulma yöntemi vardır. Przemysłowo-rolniczy 'endüstri ve tarıma ilisskin', słodko-kwaśny 'tatlı ekşi', biało-czarny 'siyah beyaz', północno-zachodni 'kuzeybatıla ilgili/kuzeybatıya ait' gibi iki birim arasında kısa çizgi görülür. Bu da eşbağımlılık ilişkisi ile açıklanır. İki bileşenin anlamı birbirini tamamlar, yapıya olan katkıları eşittir, eşit bir biçimde birleşirler ve biri diğerini nitelemez. Bu özelliğin sağlaması bileşenlerin arasına "ve" (Leh.) "i” bağlacı getirilerek yapılabilir ve anlamın bozulmadığı anlaşılır: przemysłoworolniczy (przemysłowy i rolniczy) 'endüstriyel ve tarımsal' słodko-kwaśny (słodki $i$ kwaśny) 'tatlı ve ekşi', biało-czarny (biały i czarny) 'beyaz ve siyah', północno-zachodni (północny i zachodni) 'kuzeye ve batıya özgü/hem kuzeyde hem batıda'. Tüm bunlara ek olarak tireli yazılan bu tür bileşiklerin sözlüklerde bağımsız bir biçimde madde halinde yer alması da önemli özelliklerinden bir diğeridir. Görüldüğü üzere paylaşılan bileşikler sıfat + sıfat birleşiminden oluşur. Ama bileşik isimlerde ise yine her ne kadar iki bileşenin anlamsal açıdan yapıya, bütüne katkısı eşit olsa da ve iki bileşenin anlamı birbirini tamamlasa da kısa çizgi kullanılmadan bitişik yazılmalıdır. Bileşenlerinin eşitsel olduğu, birbirini yönetmediği sıralı birleşiklerde kısa çizgi kullanımını gerektiren ve gerektirmeyen yapılar kıyaslandığında aradaki farkı net biçimde belirleyenin bileşiğin türü olduğu vurgulanmalıdır. Eşdeğerli isim + isim birleşiminden oluşan bazı bileşiklerin adların yazımı şu şekildedir: chłoporobotnik 'işçi olarak çalışan köylü', klubokawiarnia 'kafe-kulüp.' Bu bileşenlerin arasına da "ve” (Leh.) "i” bağlacı getirilebilir: chłop i robotnik 'köylü ve işçi', klub i kawiarnia 'kulüp ve kafe'. 
Yukarıda değinilen klubokawiarnia ve chłoporobotnik bileşiklerinden yola çıkarak işlevsel açıdan incelendiğinde Lehçe bileşik adların oldukça çeşitlendirilmiş sınıflara ayrildığ1 görülür. (klub 'kulüp' + kawiarnia 'kafe'), chłoporobotnik (chłop 'köylü' + robotnik 'işçi') kursokonferencja 'eğitim konferans1' (kurs 'kurs' + konferencja 'eğitim', marszobieg 'dönüşümlü olarak koşu ve yürüme' (marsz 'yürüyüş' + bieg 'koşu') gibi bir dizi sıralı bileşik örneğinden söz edilebilir. Bu tür bileşiklerde aralarında anlamsal olarak baş ayrımı yapılmayan bileşenlerin sıralarının potansiyel olarak tersine çevrilebilir olduğu tartışılabilir: (?kawiarnioklub, ?biegomarsz) (Kurzowa, Złożenia imienne we współczesnym języku polskim 59). Bu sinıfa ait bileşiklerin biçimsel bir varyantı iki bileşen arasında ara ek yerine klub-kawiarnia veya trawler-przetwórnia 'trol gemisi' şeklinde kısa çizgi olan ad öbekleridir ve bu öbeklerin iki ögesi de durum eki alır. Bu tip bileşikler ögeleri aynı biçim bilimsel konumda olan ögelerden kurulu olduğu için koşaçlı bileşik şeklinde adlandırılır.

Eğer bileşenler anlamsal açıdan eşdeğerli değilse ve bileşenlerden biri diğerinin niteliğini belirtiyorsa, o zaman bilindiği üzere kısa çizgi olmaksızın bitişik yazılmalıdır (małorolny 'küçük toprak sahibi', niebieskooki 'mavi gözlü', jasnoczerwony 'açık kırmız1', przeszłoroczny 'geçen y1la ait/geçen y1lki', bladoróżowy 'uçuk pembe') gibi. Bunlar bileşenlerden biri diğerini niteleyen birleşiklerdir. Baş öge ile ilk unsurun ilişkisi üzerinde yorum yapmak mümkündür. Bu yönüyle ikinci bileşene yönelik nasıl sorusunın yanıtı birinci bileşende olduğu rahatlıkla söylenebilir. Tür olarak sıfat olan północnoatlantycki 'Kuzey Atlantik’, północnobałtycki ‘Kuzey Baltık’ gibi birleşikler de bu gruba dahil edilebilir. Bir önceki paragraftaki północno-zachodni birleşiği ile karışma ihtimaline karşılık söz konusu bileşenlerin eşbağımlılık ilişkisi içinde olduğunu, dolayısıyla birinin diğerini nitelemediğini yeniden belirtmek gerekir. Fakat pótnocnoatlantycki bileşenleri ise anlamsal açıdan eşit sayılmazlar ve ilk bileşen diğerini niteler. Bir başka deyişle pótnocny 'kuzeye ait/özgü' olan ilk bileşen, ikinci bileşende belirtilen bölgenin (atlantycki 'Atlantik'e ait/özgü') kuzey kesminde neyin bulunduğunu belirtir (pótnocnobałtyckie wybrzeże 'Kuzey Baltık Kıyıları'). Ayrıca tire olmadan yazılan północnobałtycki, pótnocnoatlantycki, zachodniosłowiański, zachodniosyberyjski gibi birleşikler sözlüklerde bağımsız madde halinde yer almaz.

Bileşenleri renk olan bileşiklerin birkaçına bakıldığında farklı anlamların yüklendiği de görülür. Örneğin birbirine çok benzeyen Polonya ve Monako bayrakları renklerin farklı konumlandırılmasının dişında birbirlerine benzerlik gösterir. Bileşenlerin sıralanmasına bağlı olarak bu iki ulusun bayrakları bileşiklerle tanımlanabilir. Biało-czerwony 'beyaz-kırmızı' Polonya bayrağını tanımlamak için 
kullanılırken czerwono-biały 'kırmızı-beyaz' ise Monako bayrağını tanımlar. (Nagórko, "Polish" 2837)

\section{İç Merkezli / D1ş Merkezli Bileşik Sözcükler}

Lehçe ad + ad veya sıfat + ad birleşikler anlam bilimsel ve dilbilgisel ilişkiye göre sınıflandırıldığında çoğunluğu niteleyen bileşik sözcüklerin oluşturduğu görülür. Örneğin, pótśrodek 'tam çözüm sağlamayan yöntem', baletmistrz 'bale eğitmeni', drobnoustrój 'mikroorganizma', językoznawca 'dil bilimci', bajkopisarz 'fabl yazar1'. Bajkopisarz 'fabl yazarı', bir türde yazan yazarı gösterdiği için; baletmistrz 'bale eğitmeni', bir eğitmen türüne işaret ettiği için bileşik sözcüğün tamamı baş ögenin alt türünü oluşturur ve bu yüzden bu örnekler iç merkezli bileşiktir (Leh. złożenia endocentryczne). Bu tür birleşikler hiyerarşik yapıya sahiptir, bileşenlerden biri baş öge işlevi görür ve yapısal bağlamda doğru şeklin bu olduğu yönünde önceden genel bir kanı vard1. Ancak dil doğası gereği sürekli gelişmekte olduğu için bazı düşünceler de değişmek zorunda kalmaktadır.

Yakın zamana kadar, doğru biçimde oluşturulmuş bileşiğin
parçalarının baş öge-tümleyen gibi hiyerarşik bir yapıya sahip olması
gerektiği düşünülüyordu, örneğin jasnozielony 'açık yeşil', yani (yeşilin
açık tonu), bajkopisarz 'masal yazarı' (masal yazan). Günümüzde,
chłoporobotnik 'köylü işç' (chłop i robotnik - köylü ve işçi),
meblościanka 'duvar ünitesi' (mebel i ścianka - mobilya ve duvar),
zlewozmywak 'lavabo' (zlew i zmywak - lavabo ve bulaşık
bezi/süngeri), stropodach 'düz çatı' (strop i dach - tavan ve çatı) gibi
bazı sıralı yapılar da dil bilgisinde normatif nitelikte kabul görmüştür.
(Markowski 1780-1781).

Bileşenlerinden herhangi birinin baş öge olmadığı, yani başın birleşiğin içinde değil, dışında olduğu ve alt tür özellik göstermeyen dış merkezli bileşikler (Leh. złożenia egzocentryczne) obcokraj-owiec 'yabanc1', półgłów-ek 'yarım akıllı' jadłodajnia 'aşevi' şeklinde son ek içerebilir veya trójskok 'üç adım atlama', wielobok 'çokgen' şeklinde herhangi bir son ek içermeyebilir. Bu tür yapılarda baş öge ya trój-skok birleşiğinde olduğu gibi belirtilmemiştir ya da obc-o-kraj-owiec birleşiğindeki gibi son ekle sembolize edilmiştir. Obcokrajowiec örneği başka bir açıdan ele alınırsa, -owiec ekiyle kişiye ilişkin bir anlamın yüklendiği varsayıldığında dış merkezli olmaktan çok iç merkezli olarak görülebilir. Bu şekilde alternatif bakış açılarıyla zaman zaman karşılaşılabilmektedir. Sıralı bileşikler incelendiğinde ise farklı yaklaşımlar söz konusu olabilmektedir. Örneğin barmanokelner 'garson ve barmen', gadoptak 'arkeopteriks', spódnicospodnie 'pantolon etek' gibi eşitsel birleşikler ya iki baş öge 
içeren iç merkezli birleşikler olarak ya da başın birleşiğin dışarıda olduğu dış merkezli birleşikler olarak değerlendirilebilir. (Cetnarowska 284).

Lehçede ayrıca bileşenlerinden biri eylem kökü olan dış merkezli birleşikler de oldukça yaygındır ve bu eylemcil yapılar birleşik sözcüklerin oluşumunda eylem+ad ya da ad+eylem kombinasyonuna sahip olup oldukça üretkendir. Bu tür birleşiklerin kuruluşunda eylem kökleri birinci veya ikinci bileşen olup olmadıklarına bakılmaksızın baş ögeyi nitelemektedir.

pędz-i-wiatr 'başıboș, pervasız' $\rightarrow$ pędzić 'sürmek' + wiatr 'rüzgar',

baw-i-damek 'çapkın erkek' $\rightarrow$ bawić 'eğlendirmek' + dama 'leydi',

włócz-y-kij 'boş boş dolaşan' T’włóczyć çekmek, sürümek + kij 'sopa, çubuk' piorun-o-chron 'yıldırımsavar' $\rightarrow$ piorun 'yıldırım' + chronić 'korumak',

lin-o-skocz-ek 'ip cambaz1' $\rightarrow$ lina 'ip, halat' + skoczyć 'zıplamak',

list-o-nosz 'postac1' $\rightarrow$ list 'mektup' + nosić 'taşımak' bileşenlerinden oluşur.

Lehçe iç merkezli eylemcil birleşiklerde bileşenlerin bir araya gelmesi isim, fiil ve bir ek sıralaması ile sınırlı olsa da bunların dış merkezli bileşiklerde altı tür karşı1ığı vardır:

Tip 1 İsim + ara ek + Fiil + son ek (jadt-o-daj-nia)

Tip 2 İsim + ara ek + Fiil $+\varnothing($ piorun-o-chron-ø)

Tip 3 Zarf + ara ek + Fiil + son ek (now-o-rod-ek)

Tip 4 Zarf + ara ek + Fiil $+\varnothing($ dalek-o-widz-ø)

Tip 5 Fiil + ara ek + İsim + son ek (gryz-i-piór-ek)

Tip 6 Fiil + ara ek + İsim + ø (mocz-y-morda-ø) (Kolbusz-Buda 133).

İki ögesinin de anlamını koruduğu Lehçe bileşik sözcüklerin yanı sıra biçimsel açıdan bileşenleri bağımsız olmayan ve tek başına kullanılamayan birleşikler de vardır. Hatta bazen hiçbir anlam ifade etmez hale gelirler. Anlam bilimsel ölçüte göre de bileşik sözcüklerin iki ögesi yan yanayken yeni ve bağımsız bir anlam ortaya çıkar, tek başına kullanıldıklarında bazen bir anlam ifade etmezler. Bu durum baş ögenin geçirimli olup olmadığına bağlıdır. Geçirimsiz olanlar ise genelde metaforiktir: wiercipięta sözcüğü sözcüğüne çevirisi '-huzursuzluktan-durmadan topuğunu kıpırdatan kişi'dir ve sokak diline özgü olup 'telaşl1, yerinde duramayan, kurtlanan' anlamında kullanılan birleşiktir ve geçirimli değildir. Bileşenlerden hiçbiri birleşiğin bütünü hakkında bilgi vermez. Ancak her iki bileşenin anlamı bir araya getirildiğinde 
birleşiğin anlamı çözülür. Obieżyświat 'gezmen' gibi bileşenlerin anlamını koruduğu birleşik sözcük olarak kabul edilen örnekler de vardır. Burada anlam birleşmesinden söz edilebilir. Bilessenler her ne kadar anlamını korusa da tek başına kullanıldıklarında birleşik sözcüğün anlamının toplamından farklı bir anlama sahiptir. Lehçe diş merkezli birleşimsel birleşiklerin ögelerinin her zaman anlamlı unsurlardan oluştuğunu söylemek güçtür: "noworodek 'yeni doğmuş' eylemcil birleşiğinden, *rodek '? yavru', gryzipiórek 'stradan ofis çalışanı' birleşiğinden *piórek '?', bawidamek 'çapkın' birleşiğinden *damek '?’” (Kolbusz-Buda 93) bileşenleri bütünden ayrıldığında tümüyle anlamdan yoksun kalmış olur. Benzer biçimde fiilden türetilen isim gövdeleriyle birlikte oluşturulmuş birleşiklerden yola çıkarak bileşenlerinden bir tanesinde fiilin mastar hali bulunabilir düşüncesi de yanıltıc1 olabilir: bydłobójnia 'kesimhane' bileşiğinden *bydłobić 'sığır kesmek', jadłodajnia 'aşevi' birleşiğinden *jadłodać 'yiyecek vermek', snopowiązałka 'biçerbağlar' birleşiğinden *snopowiazać ‘biçip bağlamak', noworodek 'yeni doğmuş' birleşiğinden *noworodzić 'yeni doğurmak' (Kolbusz-Buda 93) gibi birleşikler üretmek olanaksızdır. Aynı şekilde Lehçe iç merkezli bileşik isimlerin aksine sağ tarafta kök ve bir ekin kombinasyonu olan diş merkezli eylemcil bileşik isimlerin ikinci bileşeni Lehçede çok nadir bağımsız bir sözcük olarak bulunur: *dajnia < jadłodajnia, *chron < priorunochron 'yıldırımsavar', *damek < bawidamek. (Kolbusz-Buda 133).

Lehçe bileşik sözcüklere yapısal açıdan bakıldığında son derece zengin ve karışık yapıya sahip olduğu anlaşılır. Ortak oluşturucuların, bir başka deyişle ara ekle birlikte yan yana olan ve bir bileşiğin yapısına katkıda bulunan morfolojik ögelerin ortaya çıkması karışıklık yaratan faktörler arasındadır. Gövde + b. ünlüsü + gövde + son ek yapısından yola çıkarak król-o-bój-stw-o $(\mathrm{kral}+\mathrm{b}$. ünlüsü + öldür + son ek + nom.tekil) 'kral öldürme' ve krwi-o-daw-ca (kan + b. ünlüsü + ver + son ek + nom.tekil) 'kan bağışçısı' hem birleştirme ünlüsü hem de sonda bulunan yapım eki ortak oluşturucu olarak işlev görür. (Cetnarowska 283). Lehçede formacje interfiksalno-sufiksalne 'ara ek-son ekli yapılar' adı verilen bu tür birleşiklerde dawca 'veren, verici' gibi adlaştırıcı ek ile birlikte sağ taraftaki fiil gövdesi başlı başına bağımsız sözcük oluşturabilir ya da *bójstwo ‘öldürme?’ gibi bağımsız biçim olarak tam doğrulanamamış olabilir. Çünkü Lehçede bójstwo tek başına görünmez ve sözce oluşturamaz, her zaman bir sözcük gövdesine eklenmesi gereken, başka birimlerle birlikte anlam kazanan bağımlı biçimbirimlerden yalnızca bir tanesidir. 
Bileşiklerin bir başka özelliği de ara ekle yan yana olan ve bileşiğe anlamsal değil yapısal katkı sağlayan morfolojik unsurların, yani oluşturucuların sık sık ortaya çıkmasıdır. Hem bir ara ek hem de ulamların fonolojik oluşumu olarak birlikte işlev gören bir son ek vardır. Bu durum Lehçe dilbilim terminolojisinde formacje interfiksalno-sufiksalne "ara ek-son ekli biçimler" şeklinde adlandırılır. Örnek olarak nos 'burun' ve róg 'boynuz' bileşenleri ile kökteki son sesin damaksıllaşmasıyla birlikte -ec adlaştırma son ekinin oluşturduğu nos-o-roż-ec 'gergedan' birleşiği incelenebilir. Çünkü *nos-o-róg gibi bir birleşikten ne de olsa söz edilemez. Bileşik oluşturma söz konusu olduğunda bağlama ünlüsünü yanı sıra $-e c$, -owiec, $-i s t \cdot a,-c \cdot a$ gibi son eklerin oluşturucu konumu olduğu görülür.

\begin{tabular}{|c|c|c|c|c|}
\hline Gövde 1 & & Gövde 2 & & Bileşik Adlar \\
\hline obc·y 'yabanc1' & + & kraj 'ülke' & $>$ & obc-o-kraj-owiec 'yabancı' \\
\hline prac·a 'meslek, iş' & + & daw-a·ć 'vermek' & $>$ & prac-o-daw-c·a 'işveren' \\
\hline gryź·ć '1sirmak' & + & $\begin{array}{l}\text { piór·o 'dolma } \\
\text { kalem' }\end{array}$ & $>$ & $\begin{array}{l}\text { gryz-i-piór-ek 'sıradan bir ofis } \\
\text { çalışanı }\end{array}$ \\
\hline pierwsz'y 'birinci' & + & klas'a 'sinif' & $>$ & $\begin{array}{l}\text { pierwsz-o-klas-ist·a 'birinci sınıf } \\
\text { ögrrencisi' }\end{array}$ \\
\hline rzecz 'şey, eşya' & + & $\begin{array}{l}\text { zna·ć 'bilmek, } \\
\text { tanımak' }\end{array}$ & $>$ & rzecz-o-zna-wc·a 'uzman' \\
\hline usług·a 'hizmet' & + & daw-a·ć 'vermek' & $>$ & $\begin{array}{l}\text { usług-o-daw-c·a 'girişimci, hizmet } \\
\text { veren' }\end{array}$ \\
\hline krótk·i 'k1sa' & + & dystans 'mesafe' & $>$ & $\begin{array}{l}\text { krótk-o-dystans-owiec 'k1sa } \\
\text { mesafe koşucusu' }\end{array}$ \\
\hline cudzy 'yabanc1' & + & $\begin{array}{l}\text { ziemi·a 'kara, } \\
\text { toprak' }\end{array}$ & $>$ & cudz-o-ziemi-ec 'yabancı' \\
\hline
\end{tabular}

Listedeki birleşiklerin her birinin bir son ek ile bittiği görülmektedir.

Son eklerden olan -ec, -owiec, -ist·a, -c·a ve -ek bu işlevde oldukça yaygındır, böylece birleşik söz konusu olduğunda, bağlama ünlüsüyle birlikte oluşturucu ögelerin bir kısmını kapsadıkları söylenebilir. (Szymanek 53).

Son ekler sözcük gövdesine eklenmesi gereken, başka birimlerle birlikte bulunan bağımlı biçimbirim olduklarından hiçbir zaman tek başına görünemezler. Yapım eki veya sesbilimsel olarak gerçekleşmeyen sıfır biçimbirim formunda dışarıdan eklenen diğer ekler söz dizimsel ulam, cinsiyet, sayı ve durum gibi biçimsözdizimsel (morfosentaktik) özelliklerini belirleyerek sözcüğü bir bütün olarak değiştirir. Bu nedenle son ek, biçimsözdizimsel baş işlevi görür. Sesbilimsel içeriği 
olmayan sıfır biçim birimi aracılığıyla bir dil bilgisel ulamının bir başka ulama dönüştürüldüğü ve çekimsel evrişime yol açtığı da ayrıca belirtilmelidir.

\section{Yapım eki}

wyrw-i-racz-ka 'kayakçıları çeken araç’; -ka: tekil, dişil, yalın

dom-o-kráz-ca 'seyyar satıcı'; $\quad$-ca: tekil, eril, yalın

now-o-rod-ek 'yeni doğmuş'; $\quad$-ek: tekil, eril, yalın

skór-o-bi-cie 'kırbaçlama cezası' $\quad$-cie: tekil, yansı, yalın

ø ek - çekimsel türetme belirleyicisi (evrişim)

$$
\begin{array}{ll}
\text { gol-i-broda-ø 'berber'; } & -\varnothing: \text { tekil, eril, yalın } \\
\text { piorun-o-chron-ø 'yıldırımsavar'; } & -\varnothing: \text { tekil, eril, yalın } \\
\text { bruk-o-tłuk-ø 'başıboş dolaşan'; } & -\varnothing: \text { tekil, eril, yalın } \\
\text { wod-o-ciag-ø 'su dağıtım tesisatı'; } & -\varnothing: \text { tekil, eril, yalın }
\end{array}
$$

Lehçe dilbilim literatüründe çekimsel evrişim terimi taban ile türetilmiş sözcük arasındaki farkın çekim paradigmalarındaki farklılığa dayandığı eksiz sözcük türetimi sürecini ifade etmek için kullan1lır. (Kolbusz-Buda 121).

Golibroda bileşiğindeki bileşenlerle yani broda 'sakal' adı ve golić 'traş etmek' fiili bir tümce içinde birlikte kullanıldığında, broda adı söz konusu fiilin nesnesi konumunda olup doğrudan etkileneceği için belirtme durum eki olan -e eki alır. Çünkü Goli brodę tümcesinde brod-e belirtme durumundadır. Birleşik oluşumunda

\begin{tabular}{|c|c|c|}
\hline Gövde 1 & Gövde 2 & Bileşik Adlar \\
\hline droga 'yol' & wskaz(ać) 'göstermek' & drog-o-wskaz:ø 'yön levhası' \\
\hline woda 'su’ & mierz(yć) ‘ölçmek’ & wod-o-mierz·ø ‘su sayacı’ \\
\hline ręka 'el' & pis(ać) 'yazmak' & ręk-o-pis`ø ‘el yaz1s1’ \\
\hline korek 'tıpa, mantar' & ciag(ać) 'çekmek' & kork-o-cią. $ø$ 'tirbuşon' \\
\hline
\end{tabular}
chron, tłuk, ciag tabanları ile diğer bileşenler arasındaki ilişki anlam bilimseldilbilgisel açıdan birbirini tamamlar. Bu birleşiklerde bileşenlerden biri diğerinin nesnesi konumundadır ama ortaya çıkan sözcük artık isimdir.

$\mathrm{Bu}$ ve bir önceki kısımda verilen sıfır biçimbirimli bileşik sözcüklerden yola çıkarak sağ bileşeni fiil kökü olan cienko-pis·ø, 'ince uçlu kalem', śrub-o-krętø 'tornavida', kork-o-ciag.ø 'tirbusson', dalek-o-widz:ø 'hipermetrop', krótko-o-widz:ø 'miyop', piorun-o-chron`ø 'yıldırımsavar', fal-o-chron`ø 'dalgakıran', mocz-y-morda.ø 'ayyaş', wod-o-spad·ø, 'şelale', list-o-pad·ø 'kasım', wod-o-lot·ø 'deniz otobüsü', bruk- 
o-tłuk·ø 'aylak aylak dolaşan', paliw-o-mierz·ø 'yakıt göstergesi', ziem-o-płód•ø 'toprak mahsulü', drog-o-wskazø 'yön levhası' gibi daha pek çok eril birleşikler sıfır biçimbirimlidir demek mümkün olacaktır.

Sıfır biçimbirimiyle nitelenen bileşik türüne ilişkin olarak "ara ekli çekimsel biçimler" (Leh. formacje interfiksalno-paradygmatyczne) şeklinde tanımlanabilinen başka bir biçimsel birleşik türü daha vardır. Söz konusu birleşiklerde bağlama ünlüsü ve çekimsel oluşturucular (yani çekim paradigmasının değişimi) gibi iki öge, ortak oluşturucu olarak hareket eder (Cetnarowska 283). List-o-nosz 'postac1', długo-pis 'tükenmez kalem', grot-o-łaz 'mağara bilimci', wiatr-o-wskaz 'rüzgar tulumu', wiatr-o-łap 'veranda', maszyn-o-pis 'daktilo yazısı', kat-o-mierz 'açı̈lçer', gaz-o-mierz 'gazölçer'. Bu tür ara ekli çekimsel bileşiklerin sağ kısmındaki tabanlar, isme evrişimleri (yani çekimsel türetme) sonucu adlaşmış fiil kökleridir. Ancak paylaşılan tabanlar üzerinden gidilirse ortaya çıkan adlaşmış -nosz, -pis, -łaz, -wskaz, -łap, mierz ögeleri bağımsız biçimbirim şeklinde, tek başına ad olarak gerçekleşemez, sözce oluşturamaz. Yalnızca bileşiğin içinde ad gibi davranırlar. List 'mektup' adı ile nosić 'taşımak' eylemi birleşiminden listonosz 'postacı' anlamı türetilmiştir. Burada -nosz adlaşmış ögesi, az önce ifade edildiği gibi tek başına kullanılmaz, ama bu birleşikte 'taşıyan' olarak anlam yüklenmiştir. Długi 'uzun' - pisać yazmak', grota 'mağara' łazić 'yürümek, tırmanmak', wiatr 'rüzgar' - wskazać 'göstermek', kąt 'köşe' - mierzyć ‘ölçmek’ gibi ad-fiil birleşimi sonucu oluşan birleşiklerin paragrafın başında verilen anlamlarının tesadüf olmadığı da anlaşılacaktır.

Sıfır biçimbirimiyle nitelenen bileşiklerin yalnızca eylem kökünden oluştuğu düşüncesine kapılmak elbette yanlış olur. Lehçede birleşimsel (eylemcil) bileşik isimlerin oluşumunda sıfır morfemin aktif bir biçimde dahil olduğunu gösteren örneklerin yanında yapısı zorunlu olarak bir fiile dayanmayan birleşikler de vardır. (Örneğin, Ad + Ad-ø głowonóg 'kafadan bacakl1lıar', stawonóg eklem bacaklılar) (Kolbusz-Buda 114).

Anlam bilimsel ve dilbilgisel ilişkilere göre de sınıflandırılabilen birleşiklerden buraya kadar niteleyen ve sıralı birleşik türleri ele alındı. Bunun dışında tümleyen birleşiklerden ve özelliklerinden de söz edilmelidir. Bu tür birleşikler yapısal olarak incelendiğinde birleşimsel (eylemcil) olduğu göze çarpar. Çünkü ikinci unsur eylemdir ya da eylemden türemiştir. Tıpkı yukarıda verilen drogowskaz, wodomierz, rękopis, korkociag birleşiklerinin yanında pracodawca, wiatrowskaz, katomierz, złotodajny gibi daha pek çoğu tümleyen birleşik türüne dahil edilebilir. 


\section{Lehçe Bileşiklerde Dilbilgisel Cins Ulamı}

Çalışmanın bu kısmına kadar verilen birleşikler arasından (örn. starodruk, żywopłot, długodystansowiec, siarkowodór, gryzipiórek) ünsüzle bittiği için dilbilgisel cins olarak eril sayılır. Yalın durumda olup cins özelliğini göstermesi dışında dilbilgisi ulamı olmayan birleşiklerdendir. Erkek cinsten sayılmalarının nedeni bileşiğin sözlüksel ulamını belirleyen biriminin yani yöneten baş ögenin (druk, płot, dystansowiec, wodór, piórek) eril cins olmasıdır. Ancak bazı birleşiklerde dişilden yansız veya erile doğru dilbilgisel cins bağlamında sapmalar söz konusu olabilmektedir. Önceki kısımlarda son ekle biten birtakım Lehçe birleşiklerden söz edildikten sonra bağımsız sözlükbirimken başka cins ulamı birleşiğin ikinci unsuruyken başka cins ulamına sahip bileşik sözcükler için de birkaç örnek vermek gerekecektir.

\begin{tabular}{|l|l|l|}
\hline Gövde 1 & Gövde 2 & Bileşik Adlar \\
\hline woda ‘su' & $\begin{array}{l}\text { głowa ‘baş, kafa' (dişil } \\
\text { cins) }\end{array}$ & $\begin{array}{l}\text { wod-o-głowie 'hidrosefali' } \\
\text { (yansız cins) }\end{array}$ \\
\hline płaski ‘düz' & stopa 'ayak' (dişil cins) & $\begin{array}{l}\text { płask-o-stopie 'düztaban' } \\
\text { (yansı cins) }\end{array}$ \\
\hline czarny ‘siyah' & $\begin{array}{l}\text { ziemia 'yer, toprak' (dişil } \\
\text { cins) }\end{array}$ & $\begin{array}{l}\text { czarn-o-ziem‘ø 'humus' } \\
\text { (eril cins) }\end{array}$ \\
\hline
\end{tabular}

Bükünlü dil olan Lehçede adların tekil/çoğul ayrımının yanında eril, dişil, yansız olma özellikleri dilbilgisel cinsiyet ulamını oluşturur. Doğal cins dişında sözcüğün son harfi dilbilgisel cinsi gösterir ve istisnalar dişında genel kural çerçevesinde "a" ünlüsüyle biten sözükler dişil olarak kabul edilmektedir. Ancak bir sözcük yalın durumda bağımsızken sahip olduğu dilbilgisel cins özelliği ile yine yalın durumda ve yapısal özelliğinde hiçbir değişiklik yaşanmamasına, temel biçimini korumasına karşın birleşiğin bileşenlerinden biri olduğunda gösterdiği dilbilgisel cinsiyet özelliği arasında farklılar görülebilmektedir.

Bileşiklerde çekimsel evrişim, bir söz dizimsel ulamdan diğerine geçişi içerebilir veya aynı söz dizimsel ulam içinde gerçekleşebilir. Çekimsel evrişime uğramış olan chronić 'korumak', tłuc 'boş boş dolaşmak', ciagnaçć 'çekmek' fiilleri isimleşirken eril bileşik olan golibroda, liżyłapa ve głowonóg, cinsiyetlerini isim soylu dişil olan broda ve łapa bileşenlerinden almaz. (Kolbusz-Buda 122).

Mucha (dişil) - burczymucha (eril) 'mızmız', pięta (dişil) - chwalipięta (eril) ‘övüngen', krupa (dişil) - liczykrupa (eril), 'varyemez', woda (dişil) - maciwoda (eril) fitne fücur', dusza (dişil) - męczydusza (eril) 'kafa ütüleyen', gęba (dişil) - moczygęba 
(eril) 'keş', pięta (dişil) - wiercipięta (eril) 'yerinde duramayan', morda (dişil) dzierżymorda (dişil) 'zorba', broda (dişil) - golibroda (eril) 'berber', łapa (dişil) - liżyłapa (eril) 'yağc1', woda (dişil) nosiwoda (eril) 'sucu' gibi sözcüklerde herhangi ses değişikliği yaşanmaması bakımından bir önceki paragrafta konu edilen birleşiklerden tümüyle farklı biçimde gramatik cins sapmaların görüldüğü bileşiklere ilişkin örnekler çoğaltılabilir.

Yukarıdaki eylemcil örnekler Lehçe birleşiklerin çok önemli bir diğer özelliğini gözler önüne serer. İkinci kök bileşen, yönetim ilişkisinin yansızlaşmasına uğrar. Bir başka deyissle chwalipięta, nosiwoda, moczymorda, liczykrupa birleşiklerinde altı çizili olan fiillerin, artık kendisinden sonraki adlarda durum eki gibi olması gereken dilbilgisel özelliğin belirlenmesini sağlayan yöneten baş konumunda olmaması nedeniyle pięta, woda, morda, krupa bileşenleri nominatif durumdadir. Adlar artık fiillerin öncül-yönetimi altında değildir. Oysa söz dizimsel ifadelerde karşıllğı ten, kto chwali pięte, nosi wode, moczy morde, liczy krupe şeklinde adlar akuzatif durumundadir. (Kolbusz-Buda 21).

Yukarıdaki pragraflarda (głowa-wodagłowie, stopa-płaskostopie, ziemiaczarnoziemø) gibi ikinci bileşenin son kısmındaki ses değişikliğiyle birlikte meydana gelen gramatik cins sapmalarından söz edilmişti. Bileşiklerin bir bölümünde ise ikinci kısmında yer alan sözlüksel birim yalın durumdaki biçimine kıyasla durum eki almış gibi görünse de dilbilgisel açıdan cinsi değişmez. Pusty 'boş' ve baş öge słowo 'sözcük' (yansız cins) birleşiminden pust-o-słowie 'laf kalabalı̆̆1' (yansız cins) türetilmiştir. Çekim paradigmaları farklı da olsa (słowo ve słowie) gramatik olarak yansız cinstir. Gramatik cins sapmaları ve farklı çekim paradigmaları kapsamında ele alınan örneklerin hemen hepsinde bağlayıcı biçimbirim olarak sadece -oünlüsünün yer alması dikkatleri çeken bir diğer noktadır.

(Wodogłowa yerine) wodogłowie'nin bileşik durumu iki şeyle belirtilir: birincisi, her zamanki -o- bağlayıcısının olması ve ikincisi gramatik açıdan cinsiyet sınıfı değişikliği, ki bu da ayrı bir çekim paradigmasıyla sonuçlanır (tekil durumda sözcük-biçimlerin bazıları: głow·a $a_{\text {NOM. }}$,

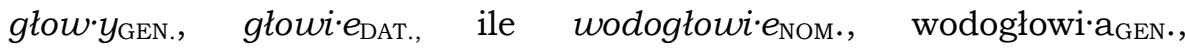
wodogłowi· u $u_{\text {DAT. }}$ gibi). Üçüncüsü, yukarıdaki yansız cins birleşiklerde (wodagłowie, płaskostopie, czarnoziem) gövdedeki son ünsüzün karakteristik damaksıllaşmasından bahsedilebilir. Bu etkiden dolayı çekimsel değişim -o- ara eki ile birlikte söz konusu bileşiğin yapısını belirleyen önemli bir ortak oluşturucu olarak düşünülebilir. (Szymanek 54). 


\section{Yapılarına Göre Bileşik İsim ve Bileşik Sıfatlar}

Lehçe bileşikler kendi aralarında bileşik isim ve bileşik sıfat olmak üzere ikiye ayrılır. Ardından her ikisi de baş ögesi isim olup eşitsel olmayan yapılar, baş ögesi fiil olan yapılar, eşitsel/sıralı yapılar, baş ögesi sıfat olup eşitsel olmayan yapılar, baş ögesi fiil olup eşitsel olmayan yapılar şeklinde birbirinden farklı sınıflara ayrılır:

I. Bileşik isimler

A1. Baş ögesi fiil olup eşitsel olmayan yapılar:

1. (fiil + isim) isim - gryzipiórek 'sıradan ofis çalışan1, başarısız yazar', pasibrzuch 'aylak obur', łamistrajk 'grev kırıc1'

2. (isim 1 + fiil) isim 2 - pracodawca 'işveren', płetwonurek 'balık adam', gradobicie 'dolu firtınası'

3. (zarf + fiil) isim - skrytobójca 'suikastçı', wieloródka 'birden fazla doğuran kadın veya dişi hayvan', brudnopis 'karalama'

4. (zamir + fiil) isim - samozaparcie 'direşme', samoobrona 'nefsi müdafaa', samograj 'az emekle çok beğenilen yapıt, kendiliğinden ses çıkaran enstrüman'

5. (sayı + fiil) isim - półtrwanie 'yarı ömür', trójskok 'üç adım atlama', dziesięciobój ‘dekantlon’

A2. Baş ögesi isim olup eşitsel olmayan yapılar:

6. (isim $\left.1+\operatorname{isim}_{2}\right)$ isim $_{3}$ - nosorożec 'gergedan', stawonóg 'eklem bacaklılar', wodogłowie 'hidrosefali'

7. (sıfat $\left.+\operatorname{isim}_{1}\right) \operatorname{isim}_{2}-$ niskociśnieniowiec 'düşük tansiyonlu', pięknoduch 'güzelliğe çok önem veren', płaskostopie 'düztaban'

8. $\left(\operatorname{say}_{1}+\operatorname{isim}_{1}\right)$ isim $_{2}$ - pierwszoklasista 'birinci sınıf', jednorożec 'tek boynuzlu at', trójdźwięk 'üçlük akort', tysiaclecie 'milenyum'

B. Eşitsel/sıralı yapılar:

9. ögelerin dilbilgisel bağlamda birleşimsel olmaları açısından bakıldığında her zaman şu tipte yapılar vardır: $\left(\operatorname{isim}_{1}+\operatorname{isim}_{2}\right) \operatorname{isim}_{3}$ bkz.: barakowóz 'tekerlekli prefabrik yapı' (hem kurma hem de araba olan bir şey), benzer biçimde: chłoporobotnik köylü işçi, gadoptak 'çok eski dönemlerde sürüngen ve kuş özelliklerine sahip hayvan, sürüngen kuş' komediodramat komedi-drama, płucoserce 'kalpakciğer makinesi', zlewozmywak 'eviye"'

II. Bileşik Sifatlar 
A1. Baş ögesi sıfat olup eşitsel olmayan yapılar:

1. tip ( sifat $_{1}+$ sifat $\left._{2}\right)$ sifat $_{3}$ - ciemnobłekitny 'koyu mavi', jasnoszary 'açık gri'

2. tip (zarf + sifat $\left._{1}\right)$ sifat $_{2}$-równowarty 'eş değer', wiecznożywy 'ebedi diri'

3. tip (sayı + sıfat 1$)$ sıfat 2 - półszlachetny 'yarı değerli', półpogański 'yarı pagan'

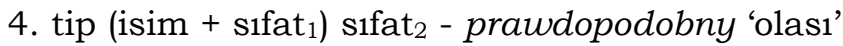

A2. Baş ögesi isim olup eşitsel olmayan yap1lar:

5. tip (sıfat ${ }_{1}+$ isim) sıfat 2 - małomiasteczkowy 'küçük kasabaya özgü', całonocny 'gece boyu süren', złotousty 'güzel konuşan', pełnokrwisty 'safkan, gerçek'

6. tip (say1 + isim) sifat - jednoreki 'tek kollu', pieccioramienny 'beş kollu', wielogłowy 'çok başl1', trzydniowy 'üç günlük'

7. tip (isim $1+$ isim $\left._{2}\right)$ sifat - laskonogi 'ince uzun bacakl1', błonkoskrzydły 'zar kanatlilar'

A3. Baş ögesi fiil olan yapılar:

8. tip (isim + fiil) sıfat - śmiercionośny 'ölümcül', życiodajny 'hayat veren', owadożemy 'böcekle beslenen'

9. tip (say1 + fiil) sifat - dwuznaczny 'iki anlama gelebilen', trójdzielny 'üç parçadan oluşan, üç parçaya bölünebilen', obosieczny 'çift ağılıl, iki tarafı keskin'

10. tip (zarf + fiil) sifat - wszystkowiedzacy 'her şeyi bilen', pięknobrzmiacy 'kulağa güzel gelen', jasnowidzacy 'geleceği/görülmeyen şeyleri görebilen'

B. Eşitsel/sıralı yapılar:

11. tür (sıfat ${ }_{1}+$ sıfat $\left._{2}\right)$ sifat $_{3}-$ głuchoniemy 'sağır dilsiz'

12. tip (isim 1 +isim 2 ) sifat - miodomleczny 'ballı süt' (bal ve süt içeren), tanr1-insan (hem Tanrı ve hem insan olan), suda ve karada yaşayan (wodoziemne zwierzęta amfibi hayvanlar) (Nagórko, Zarys gramatyki polskiej 211). 


\section{Rol Dökümü}

Lehçe birleşiklerin anlamsal yapısının oldukça çeşitli olduğu ve bazen karmaşık olduğu görülmektedir. Bununla birlikte tam anlamıyla bir anlamsal sınıflandırmasını vermek de pek kolay olmamaktadır. Rol dökümü adı verilen eylem tarafından birleşiklere yüklenen ve başın anlamsal içeriğiyle belirlenen anlam bilimsel özellikten de söz etmek yerinde olacaktır. Aşağıdaki birleşiklerde ne tür rollerin bulunduğu ve bunların nasıl adlandırıldığı liste halinde sunulmuştur:

\begin{tabular}{|l|l|}
\hline Eden/K1lıc1 & listonosz 'postac1', marnotrawca 'müsrif' \\
\hline Olay & płodozmian 'ekim nöbeti', krwotok 'kanama' \\
\hline Araç & ciśnieniomierz 'bası̈̈lçer', długopis 'tükenmez kalem' \\
\hline Yer & wiatrołom 'rüzgârın ağaçları devirdiği alan', bydłobójnia 'kesimevi' \\
\hline Sonuç & brudnopis 'müsvedde', rękopis 'el yazısı' \\
\hline Deneyimci & głodomór 'doymak bilmeyen' \\
\hline Etkinlik & grzybobranie 'mantar toplama' \\
\hline Durum/Koşul & płaskostopie 'düztaban' \\
\hline Bölge sakini & Nowozelandczyk 'Yeni Zelandalı' \\
\hline Hedef & wydrwigrosz 'üçkağıtç1, dolandırıc1' \\
\hline Zamansıl & listopad 'kasım' \\
\hline Niteleme & Lekkoduch 'pervası, umursamaz' \\
\hline
\end{tabular}

Ancak anlamsal sınıflandırmada zorluk çekilen noktalar da yok değildir. İki farklı sınıfa aynı anda dahil edilebilen birleşiklere de rastlanılmaktadır:

burczymuchaø 'mızmı' (Eden, Karşılaştırma): -motamot- sinek gibi (Karşılaştırma) vızıldayan kişi (Eden)

chwalipiętaø ‘övüngen' (Eden, Etkilenen): -motamot- topuğunu (Etkilenen) öven kişi (Eden)

Liczykrupaø 'varyemez' (Eden, Etkilenen): -mot.- arpa tanelerini (Etkilenen) sayan kişi (Eden)

liżyłapaø 'yağcı, kemik yalayıcı' (Eden, Etkilenen): -mot.- el (Etkilenen) yalayan kişi (Eden)

mąciwodaø 'fitne fücur' (Eden, Etkilenen): -mot.- suyu (Etkilenen) bulanıklaştıran kişi (Eden)

męczyduszaø 'kafa ütüleyen' (Eden, Etkilenen): -mot.- ruha (Etkilenen) eziyet eden kişi (Eden)

moczymordaø 'ayyass' (Eden, Etkilenen): -mot.- suratı (Etkilenen) 1slatan kişi (Eden)

obieżyświatø 'gezmen' (Eden, Yer): -mot.- dünyayı (Yer) dolaşan kişi (Eden) 
pędziwiatrø 'başıboş, pervasız' (Eden, Karş1laştırma): -mot.- rüzgâr gibi (Karşılaştırma) koşan kişi (Eden)

włóczykijø "boş boş dolaşan" (Eden, Etkilenen): -mot.- sopayı / ucunda bohça olan sopayı (Etkilenen) sürüyen kişi (Eden)

wydrwigroszø “üçkağıtçı, dolandırıc1' (Eden, Hedef) -mot.- bir kuruşu (Hedef) hileyle koparan kişi (Eden) (Kolbusz-Buda 155)

Buraya kadar -o- ara ekinin desk-o-rolka 'kaykay', świat-o-poglad 'dünya görüşü' gibi bileşiğin ilk ögesi isim olduğunda; popularn-o-naukowy 'popüler bilim', now-o-żytny 'modern' şeklinde bileşiğin ilk ögesi sıfat olduğunda; sob-o-wtór '(birbirinin) tıpatıp aynısı' sam-o-chód 'araba' gibi ilk ögesi adıl olduğunda ve sześcio-bok 'altıgen', ośmi-o-zgłoskowiec 'sekiz heceli mısra' örnekleri gibi de bileşiğin ilk ögesi sayı olduğunda kullanıldığı sonucu çıkarılabilir. Birleşik isim, birleşik sıfat, eylemcil, ara ekli-son ekli, iç merkezli/dış merkezli birleşik ve daha pek çok birleşik türünün olduğu sonucu da çıkarılabilir. Adı geçen türlere ilişkin verilen örneklerin yanında son olarak bazı eski özel isimlerin de çalışmaya dahil edilmesi gerekecektir. Çünkü bu özel isimlere bakıldığında -o- ara ekli yapının varlığından söz edilebilir olması son derece dikkat çekicidir.

-o- ara ekli bileşikler dilde çok eskidir. Onlara birleşik özel Slav isimlerinde rastlyyoruz: Czest-o-Sław, Dobr-o-gost, Dobr-o-sław, Jar-omir, Jar-o-Sław, Mir-o-Sław, Sławo-mir. Bir diğer bileşik türü ilk birim olarak fiil içerir ve bağlama ögesi $-i$ - veya $-y$-şeklindedir. dus-i-grosz, licz-y-krupa, 'varyemez', męcz-y-dusza 'can sık1c1', pędz-i-wiatr, 'başıbos, pervasız', woz-i-woda 'sucu', wyrw-i-dąb '-masal karakteri olarak- dev, izbandut' bugün kullanılan sözcüklerdendir. Eski Lehçede 'kurtulmak, bertaraf etmek, ortadan kaldırmak' anlamına gelen zbyć fiilinden oluşturulmuş $Z b$-y-gniew ve $Z b$-y-lut gibi özel isimlerin yanında Bron-i-Sław, Budz-i-Sław, Kaz-i-mir daha sonraki hali Kaz-i-mierz, Morz-y-Sław, Mśc-i-Sław, Stan-i-Sław, Włodz-i-mierz, Włodz-i-Sław, Wroc-i-Sław şeklinde -i- (-y-) ekli birçok özel Slav isimlerimiz de vard1. Basitleştirilmiş Wrocisław ve Włodzisław isimlerinden, yani Wrockaw(s)ław ve Włodz(s)ław biçimlerinden Wrocław ve Włocławek şehir adları oluşturulmuştur. Ayrıca ilk birimi sam, sobie, wsze şeklinde zamir olan özel Slav isimleri de mevcuttu, örneğin Sam-bor, Sobie-Sław, Wsze-bor, Wsze-ciech, Wsze-mir, Wszerad, Wsze-glam. Bu isimlerdeki wsze telaffuzu zor bir zamir olarak çeşitli dönüşümlere uğramıştır. Wsze zamirinin başındaki ünsüzlerin yerleri değiştirildi ve szwe şeklinde telaffuz edildi. (Bak 230). 


\section{Sonuç}

Değişen ve gelişen dünyada yeni anlam ve kavramları karş1lamak üzere her dil, yapısına ve dil dizgesine göre birtakım sözcük türetme mekanizmasına sahiptir. Lehçede de bu yeni kavramları karşılamak üzere dil bilgisi kuralları çerçevesinde dilin bazı ifade özelliklerinden yararlanılmıştır. Bu doğrultuda eklemeli dillerden olan Lehçede öncelikle ekle türetme yoluna gidilmektedir. Ancak bazen yeni ortaya çıkmış kavramı, keşfedilmiş bir nesneyi, canlıyı ya da hastalığı karşılaması için sözcük türetme sürecinde eklerin verilmek istenen anlamı tam karşılayamadığı durumlar yaşanmaktadır. Bu yüzden ön ek ve son ek gibi sözcük yapım eklerinin yanında birden fazla sözcüğün birleştirilmesi yoluna başvurulur. Farklı anlam, tür ve yap1 özelliklerine sahip olabilen en az iki sözcüğün kurallı biçimde bir araya gelmesiyle birleşik sözcük oluşturulur.

Lehçenin bugün söz varlığında yeni kavram, varlık ve hareketleri karşılama konusunda bazı ekler yardımıla türetilmiş sözcüklerin yetersiz kaldığı yerde birleştirme özelliğinden yararlanılarak ortaya çıkarılmış birçok unsur bulunur ve böylesi üretken bir özelliğin çeşitli ölçütler çerçevesinde sınıflandırılma çabası ayrı bir güçlüğü beraberinde getirir.

Lehçe birleşiklerin oluşumunda sözcük, ön ek, son ek, parçacık ve bağımlı dilbilgisel biçimbirimler bir başka sözcükle birleşirler. Diğer bir ifadeyle bağımsız sözlüksel biçimbirim herhangi bir bağımlı dilbilgisel biçimbirim ile birleşebilir ve sözcük yapımının sağlanması sonucu yeni bir anlam ortaya çıkar. Farklı anlamlar taşıyan bu birleşik sözcüklerin -mecazi olanlar dişında- bir kısmında kendilerini oluşturan sözcüklerin gerçek anlamlarını korudukları görülür. Bir kısmında da birleşik sözcüğün kendisi ile bileşenleri olan sözcükler arasında herhangi bir anlam bağının bulunmadığı görülür. Bir kısım birleşikler ise köken bakımından karışıklık yaratır. Çünkü bileşenlerden birincisi ya da ikincisinin özellikle Latinceden veya Yunancadan geçmiş alıntı sözcük olduğu, diğerinin ise Lehçe kökenli olduğu görülür.

Ekonomik, kültürel, sosyal, teknolojik değişimler ve ticaret, savaş, göç gibi kitlesel olaylarla birlikte diller arası gelişen ilişkiler sonucu yeni kavramlar ortaya çıkar. Lehçe bileşik isimlerin bir diğer özelliği de dile yeni katılan sözlük birimler olarak bilinen neolojizmle yakın ilişkisi içinde olmasıdır.

Diğer pek çok Slav dillerinde olduğu gibi Lehçe birleşiklerin de hemen hepsinde bazı ara ekler kullanılır. Ancak birinci bileşenin son sesi veya ikinci bileşenin ilk sesinin titreşimli olup olmadığına bağlı olarak ara ekin kullanılmadığ 
da görülür. Birleşik isimler ve bileşik sıfatlar kendi içinde baş öğesi fiil/isim olup eşitsel olmayan yapılar veya eşitsel/sıralı yapılar gibi birtakım sınıflara ayrılır. Bunun dışında tümleyen, niteleyici ve sıralı olmak üzere oluşum yapısına göre ele alınan birleşik sözcükler ayrıca iç merkezli ya da dış merkezli olmaları bakımından da çeşitlilik gösterir. Oldukça sık başvurulan sözcük türetme yollarından biri olan ve bağımsız sözlüksel birim niteliği taşıyan birleşik sözcüklerin Lehçenin söz varlığında her zaman önemli bir yeri olmuştur ve olmaya da devam edecektir.

\section{KAYNAKÇA}

Bağrıaçık, Metin ve Angela Ralli. "Phrasal vs. Morphological Compounds: Insights from Modern Greek and Turkish." Language Typology and Universals 68.3 (2015): 323-357.

Bak, Piotr. Gramatyka języka polskiego. Warszawa: Wiedza Powszechna, 1984.

Bartnicka, Barbara ve Halina Satkiewicz. Gramatyka języka polskiego podręcznik dla cudzoziemców. Warszawa: Wydawnictwo Wiedza Powszechna, 1998.

Cetnarowska, Bożena. "Compounds and multi-word expressions in Polish." Complex Lexical Units: Compounds and Multi-Word Expressions. Ed. Barbara Schlücker. Berlin, Boston: De Gruyter, 2019. 279-306.

İmer, Kâmile, Ahmet Kocaman ve A. Sumru Özsoy. Dilbilim Sözlüğü. İstanbul: Boğaziçi Üniversitesi, 2011.

Jadacka, Hanna. Kultura języka polskiego -Flekcja, słowotwórstwo, składnia-. Warszawa: Wydawnictwo Naukowe PWN, 2006.

Kolbusz-Buda, Joanna. Compounding in Polish and English. Lublin: Wydawnictwo KUL, 2014.

Kurzowa, Zofia. Z przeszłości i teraźniejszości języka. Kraków: Universitas, 2007.

---. Złożenia imienne we współczesnym języku polskim. Kraków: Państwowe Wydawnictwo Naukowe, 1976.

Markowski, Andrzej. Nowy słownik poprawnej polszczyzny. Warszawa: Wydawnictwo Naukowe PWN, 1999.

Nagórko, Alicja. "Polish". Word Formation. An International Handbook of the Languages of Europe. Ed. Peter O. Müller, Ingeborg Ohnheiser, Susan Olsen, Franz Rainer. Berlin: De Gruyter Mouton, 2016. 2831-2852.

---. Zarys gramatyki polskiej. Warszawa: Wydawnictwo Naukowe PWN, 2003. 
Szymanek, Bogdan. "Compounding in Polish and the absence of phrasal compounding." Further Investigations into the Nature of Phrasal Compounding Ed. Carola Trips, Jaklin Kornfilt. Berlin: Language Science Press, 2017. 4979.

Vardar, Berke. Açıklamalı Dilbilim Terimleri Sözlüğü, İstanbul: Multilingual, 2007.

\section{Summary}

Developments in the field of sociocultural and technology in the world have brought the need for new words. Numerous words have been derived from past to present in every living language, and will continue to be derived due to the nature of the language. Depending on the typology of the language, there may be differences in word derivation methods. In addition to derivation of words using a number of prefixes and suffixes, composition, which means combining two or more words to create a new word, is among the most common and productive methods.

Forming a compound word by combining two or more units is one of the most frequently used methods in Polish language. However, compound words in Polish that will be discussed in this study are different from Turkish compound words in terms of structure. This is because Polish, like many other Slavic languages, has different affixes. These affixes appear between two components written adjacent. One of the reasons why compound words, which are a type of word according to their forms, have a different structure in this language is based on the absence of the compound noun in which the attributive noun isn't suffixed while the noun which is modified takes the third person possessive suffix.

An interesting similarity also is observed when some words in Turkish which have been borrowed from other languages are compared with the compounds in Polish and English. It can be seen that between the two units of the compound there is a linking vowel “-O-,.

As in all languages, one of the most common methods of deriving words in Polish is compound words. There are different ways to form them. The most important rule of this method is to have at least two words, not affixes. Because the suffix, as is known, can help to derivate from an existing word, not forms compound. It is also not correct to say that there is no affix between the two components. However, it should be noted that this affix does not have a word derivation function. In this respect, the type of affix in question should be determined well. When some Turkish sources that deal with words in another language belonging to the Slavic language 
family according to their structures are examined, it is observed that this suffix in the compound is called "infix". However, it would be more correct to use the term "interfix". In Polish, which is one of the inflecting languages, word roots gain different morphological shapes by having prefix, infix, interfix or suffix and also simultaneously both prefix and suffix.

Compounds are derived words formed by combining two root morphemes with the help of infixes. Depending on the fact that the verb stem, numeral, adjective and noun appear in the first part, mostly -o-, the vowels $-i-,-u$ - and $-y$ - are infixes that function as a linking element in Polish.

The simple truth is that language is living and changing. Due to this characteristic, the vocabulary is in constant development. It is seen that the compounds formed with the suffix -o- in Polish are sometimes used to give a new meaning to a newly produced concept, which is a universal phenomenon and known as neologism. Some of these new elements are not yet in the dictionaries. Therefore, the meanings of the new words to be shared in this section will be determined based on their components.

Compound words differ not only in structural but also in phonetic aspects when compared to phrases written separately. Compounds having more than three syllable have two degrees of stress, primary and secondary. The primary emphasis is on the penultimate of the second component, while the secondary emphasis is on the first component.

Compound words are divided into two groups as compound nouns and compound adjectives. Some compound adjectives consisting of coordinative adjective + adjective have a different method of forming than compound nouns in that there is a hyphen between two elements. If the components are not semantically coordinative and one of the components indicates the attribute of the other, then as is known, they should be written adjacent without hyphens.

Exocentric compounds, one of which constitutents is the verb root, are also quite common in Polish, and these synthetic structures have the verb + noun or noun + verb combination and are highly productive.

It seems that the semantic structure of Polish compounds is quite diverse and sometimes complex. It is not easy to make a semantic classification. The semantic feature, attributed to the compounds by the verb and determined by the semantic content of the head is also mentioned. 
In order to create new meanings and concepts in the changing and developing world, every language has a certain word derivation mechanism according to its structure and system. In Polish, some expression features of the language are used within the framework of grammar rules to have these new concepts. In this context, firstly derivational affix is preferred in Polish which is one of the agglutinative languages. However, sometimes the affixes can not fully meet the need of desired meaning of newly emerged concept, a discovered object or disease. For this reason, the method of combining more than one word is applied, except for derivational bound morphems such as prefixes and suffixes. Compound word is formed by combining at least two words that can have different meaning, type and structure properties. 